\title{
The Main Ecological Characteristics of a Species Introduced to Martinique in a Dynamic of Invasion: Funtumia Elastica (Preuss) Stapf (Apocynaceae)
}

\author{
Philippe Joseph $^{1}$, Kévine Baillard ${ }^{2}$, Jean-Philippe Claude ${ }^{2}$, Yelji Abati ${ }^{2}$, Séverine Ely-Marius ${ }^{2}$, Yanis \\ Jean-François ${ }^{2}$, Stéphane Sophie ${ }^{2}$, Péguy Major ${ }^{2}$, José Duranty ${ }^{2}$, Jean Emile Simphor ${ }^{3} \&$ Jean-Valery Marc $^{3}$ \\ ${ }^{1}$ Professor, UMR ESPACE DEV-BIORECA, University of the French Antilles, French \\ ${ }^{2}$ Phd Student, UMR ESPACE DEV-BIORECA, University of the French Antilles, French \\ ${ }^{3}$ Senior Lecturer, UMR ESPACE DEV-BIORECA, University of the French Antilles, French \\ Correspondence: Philippe Joseph, UMR ESPACE DEV-BIORECA, University of the French Antilles, French. \\ Tel: 596-696-206-141. E-mail: joseph.phil@wanadoo.fr
}

Received: March 7, 2019 Accepted: April 4, 2019 Online Published: April 30, 2019

doi:10.5539/jps.v8n2p1 URL: https://doi.org/10.5539/jps.v8n2p1

\begin{abstract}
Introduced species that become invasive alter the structural and functional organisation of the ecosystems of the host territories because of the absence of certain ecological locks. On a global scale, the consequences are very damaging for many key development-related sectors. Martinique, like all the islands of the Caribbean, is not immune to this phenomenon of biological invasion currently linked to greater globalisation. Among the potentially invasive introduced species and in the light of field observations, Funtumia elastica, native to tropical Africa, appears to have functional traits that could make it a species that is dangerous for local floristic diversity. Since no study exists in Martinique on the ecology of this taxon, we have set up a research protocol based on floristic surveys in various stations marked out by transects subdivided into quadrats. Using the data obtained, it has been possible to highlight the main features of the ecology of this species in terms of biodemography, ecological dominance, mesological affinities and of belonging to the different stages of vegetal succession.
\end{abstract}

Keywords: Lesser Antilles, Martinique, vegetation, Funtumia elastica, succession, invasive species, anthropisation

\section{Introduction}

Man, through his diverse activities in space and time, has altered most planetary ecosystems (Bazzaz, 1983; Ulgiati \& Brown, 1998; Dunn, 2010; Guariguata, 1990; Griffiths et al., 2014; Murcia et al., 2014). The effects of anthropogenic impacts which are uneven in intensity and frequency have resulted in a loss or decrease in ecosystemic resilience, signified by the modification, to varying degrees, of ecological locks (Margono, Potapov, Turubanova, Stolle, \& Hansen, 2014; Gunderson, 2000; Butchart et al., 2010; Gardner, Barlow, Sodhi, \& Peres, 2010; Corenblit, Steiger, Gurnell, \& Naiman, 2009; Weerman, Herman, \& Van of Koppel, 2011). In general, the hierarchical and complex organisation of the latter aims to ensure the processes of self-organisation: in particular the mechanisms of regulation and homeostasis (Deblauwe, Couteron, Lejeune, Bogaert, \& Barbier, 2011; Schoelynck et al., 2012; Lawley, Parrott, Lewis, Sinclair, \& Ostendorf, 2013; Levin, 2005; Lugo, 2013). Aside from the loss of biotopes and species, human-induced deregulation frees up sites of installation and expansion which may be occupied by certain introduced plants according to their biological profiles [Crawley, 2009; Yang, Liu, Ren, \& Wang, 2009; Peterson, 2001; Donlan \& Wilcox, 2008 (Figures 1a \& 1b)]. 


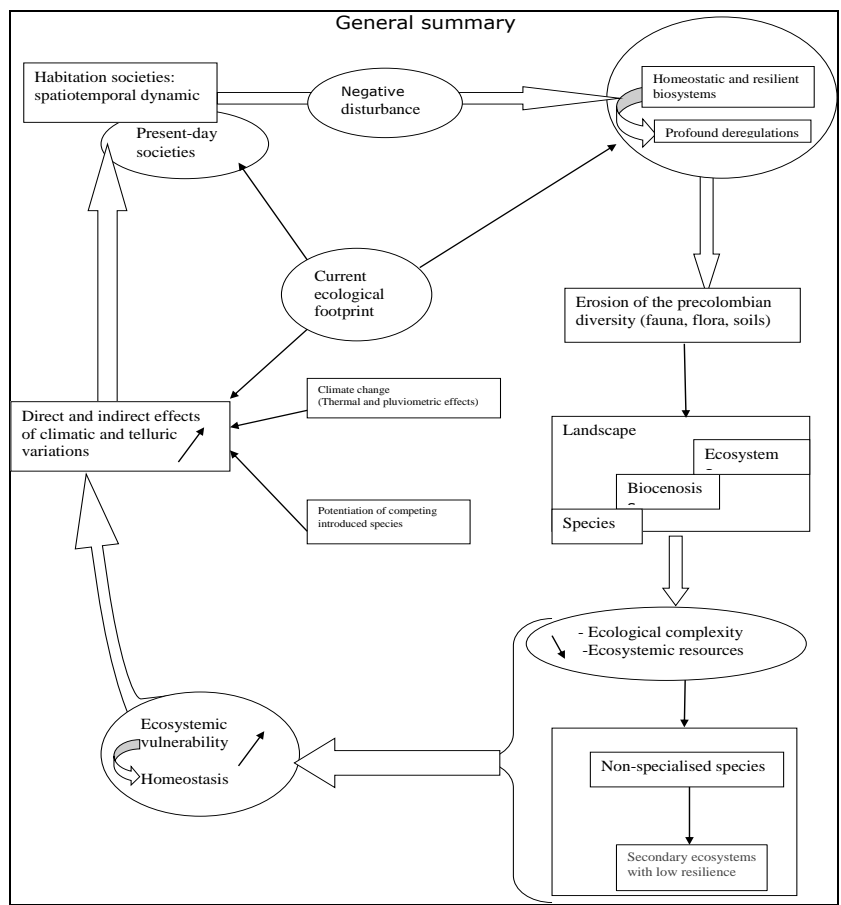

Figure 1a. Ecosystemic effects induced by the anthropisation (P. Joseph)

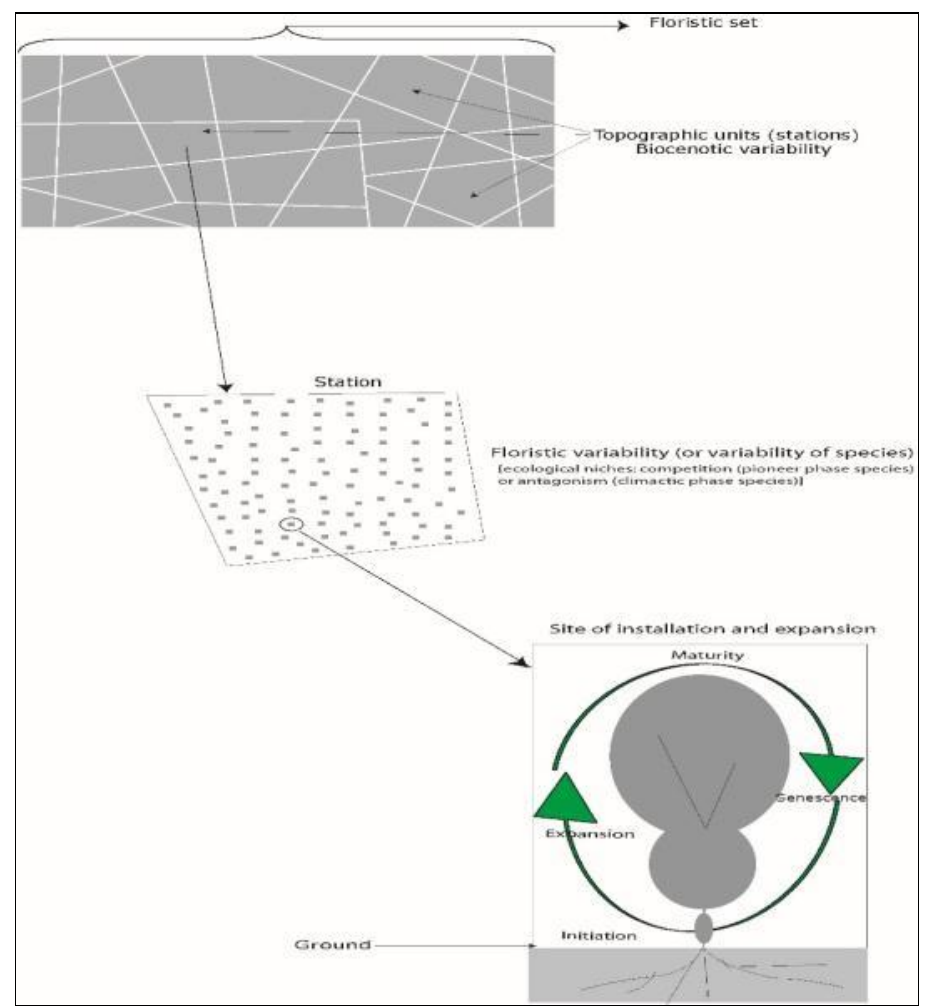

Figure 1b. Example of levels of integration within the ecosystem (P. Joseph)

Within the anthropised biosphere, in correlation with the regression of the ecosystems, the naturalised introduced species potentiate their capacity to use the mesological factors and become more and more competitive by increasing their demography (Peterson, Papes \& Kluza, 2003; Taylor \& Kumar, 2013; Ghahramanzadeh et al., 2013). During the processes of invasion, these allochthonous taxa modify host habitats for the benefit of their regeneration (Bunn, Davies, Kellaway, \& Prosser, 1998; Negussie et al., 2013; McNeely, 2001). As a result, the 
competitive level of some autochthonous species is reduced while others disappear (Boudiaf et al., 2013; Denslow, Space, \& Thomas, 2009; Figure 2).

Invasive species are one of the major causes of biodiversity erosion (Hulme, 2009; Charles \& Dukes, 2008). Whatever humanised geographic space is considered, their demographic development appears to be one of the ecosystemic responses to human activities (Gurevitch \& Padilla, 2004; Chapin et al., 2000). For various reasons, humans have encouraged and still encourage many transfers of vegetal species between bioclimatic zones (tropical and temperate, for example) (Sakai et al., 2001; Gordon, 1998; Yan, Zhenyu, Gregg, \& Dianmo, 2001; Hemp, 2008). These taxa transfers were and are both accidental and intentional and correspond to the following groups of plants (Schofield, 1989; Richardson \& Pysek, 2012; Reichard \& White, 2001; Zohary, 2004; Duncan et al., 2004): agricultural plants, ornamental plants, medicinal plants, dye plants, fruit plants, magico-religious plants (sacred plants), plants used for joinery, cabinet making and carpentry construction (Reaser et al., 2007).

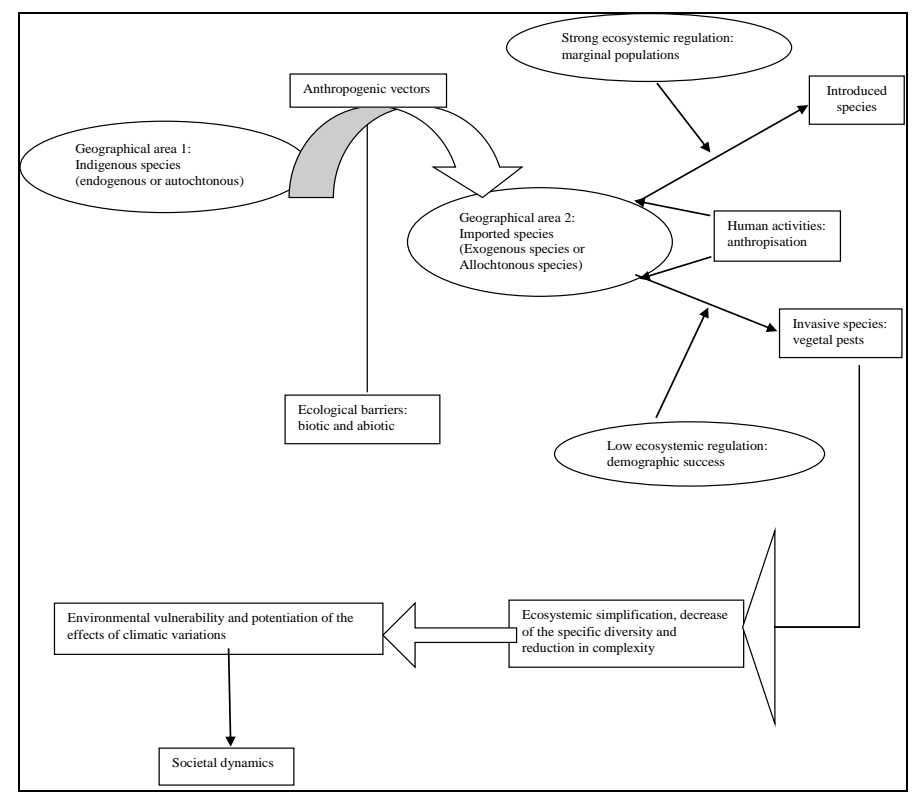

Figure 2. Dynamic of the erosion of autochtonous specific diversity (P. JOSEPH)

Species that pullulate in the continental, insular and oceanic ecosystems of Africa, America, Asia and Europe create profound ecological disorders (Zimmerman et al., 2008; Daehler, 2006; Meyerson \& Mooney, 2007). The direct consequence is the qualitative and quantitative decline of the biocenotic resources impacting economic and societal development (Dawson, Burslem, \& Hulme, 2009; Pimentel, Lach, Zuniga, \& Morrison, 2000; Mack \& D'Antonio, 1998; Holmes, Aukema, Von Holle, Liebhold, \& Sills, 2009; Figure 2). In the Caribbean, particularly in the Lesser Antilles, the phenomenon of biological invasion is also worrying as many imported species escape from gardens and agro-ecosystems and become naturalised in the natural vegetation (Kairo, Ali, Cheesman, Haysom, \& Murphy, 2003; Kairo, Pollard, Peterkin, \& Lopez, 2000; Cock, 1985; Figure 3). In fact, they (these introduced species) develop all their phenological phases in the natural vegetation by adaptation to the biophysical factors: they thus acquire ecological autonomy and are called naturalised (Sakai et al., 2001; Norghauer, Martin, Mycroft, James, \& Thomas, 2011; Maunder et al., 2008; Pejchar \& Mooney, 2009; Figure 3).

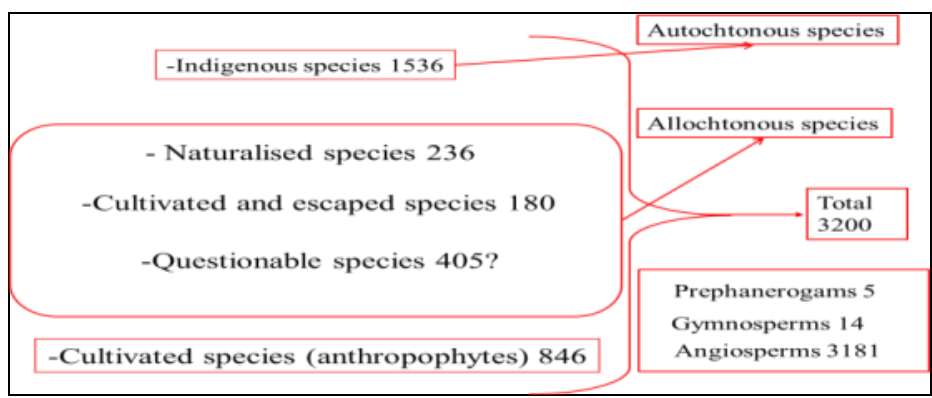

Figure 3. Some features of the phanerogamic diversity of the French Antilles 
In Martinique, among the potentially invasive plant species (Table 1), Funtumia elastica (Apocynaceae) native to Africa (Howard \& Powell, 1963; Sheil, Jennings, \& Savill, 2000) presents an aggressive dynamic in degraded formations (open herbaceous, bushy or mixed environments) and in structured secondary forest formations [quasi-closed stratified sylva environments (Mwavu \& Witkowski, 2009)]. The management of the populations of this species requires the knowledge of its life history with regard to its ecological plasticity. Based on transects in phytocenoses developing on various topographic facies and conditioned by specific bioclimates, the main ecological features of Funtumia elastica were characterised.

Table 1 . The main potentially invasive plant species in Martinique

\begin{tabular}{|c|c|c|c|c|c|c|}
\hline $\begin{array}{l}\text { Scientific } \\
\text { names/Families }\end{array}$ & $\begin{array}{l}\text { Vernacular } \\
\text { names }\end{array}$ & Origin & $\begin{array}{l}\text { Physionomic } \\
\text { types }\end{array}$ & Bioclimates & $\begin{array}{l}\text { Dynamic stages } \\
\text { (biocenotic affinities) }\end{array}$ & Dissemination \\
\hline $\begin{array}{l}\text { Spathodea } \\
\text { campanulatal } \\
\text { Bignoniacées }\end{array}$ & $\begin{array}{l}\text { African } \\
\text { Tuliptree }\end{array}$ & $\begin{array}{l}\text { Tropical } \\
\text { Africa }\end{array}$ & tree & $\begin{array}{l}\text { Humid and } \\
\text { moderately humid }\end{array}$ & $\begin{array}{l}\text { pre-forest, young forest, advanced } \\
\text { secondary forest gaps }\end{array}$ & anemochore \\
\hline $\begin{array}{l}\text { Funtumia elastica / } \\
\text { Apocynacées }\end{array}$ & Silkrubber & $\begin{array}{l}\text { Tropical } \\
\text { Africa }\end{array}$ & tree & $\begin{array}{l}\text { Humid and } \\
\text { hyper-moist }\end{array}$ & secondary forest & $\begin{array}{l}\text { Anemochore } \\
\text { Barochore }\end{array}$ \\
\hline $\begin{array}{l}\text { Dichrostachys cinereal } \\
\text { Mimosacées }\end{array}$ & Sicklebush & $\begin{array}{l}\text { Tropical } \\
\text { Africa }\end{array}$ & shrub & Dry & herbaceous bushy & Barochore \\
\hline $\begin{array}{l}\text { Mimosa malacocentral } \\
\text { Mimosacées }\end{array}$ & $\begin{array}{l}\text { Elegant } \\
\text { Mimosa }\end{array}$ & Brazil & shrub & Dry & herbaceous bushy & Barochore \\
\hline $\begin{array}{l}\text { Bambusa vulgaris/ } \\
\text { Poacées }\end{array}$ & Bamboo & $\begin{array}{l}\text { Tropical } \\
\text { Asia }\end{array}$ & $\begin{array}{l}\text { large } \\
\text { herbaceous }\end{array}$ & $\begin{array}{l}\text { Humid and } \\
\text { moderately humid }\end{array}$ & Herbaceous bushy windfall & Anemochore \\
\hline $\begin{array}{l}\text { Triphasia } \quad \text { trifolial } \\
\text { Rutacées }\end{array}$ & Limeberry & $\begin{array}{l}\text { South East } \\
\text { Asia }\end{array}$ & shrubby & $\begin{array}{l}\text { Moderately } \\
\text { humid and dry }\end{array}$ & pre-forest, young forest & $\begin{array}{l}\text { Zoochore, } \\
\text { barochore }\end{array}$ \\
\hline $\begin{array}{l}\text { Castilla elastica / } \\
\text { Moracées }\end{array}$ & $\begin{array}{l}\text { Panama } \\
\text { Rubber Tree }\end{array}$ & $\begin{array}{l}\text { Tropical } \\
\text { America }\end{array}$ & tree & $\begin{array}{l}\text { Humid and } \\
\text { moderately humid }\end{array}$ & $\begin{array}{l}\text { pre-forest, young forest, forest } \\
\text { gaps }\end{array}$ & Zoochore? \\
\hline $\begin{array}{l}\text { Thunbergia grandifloral } \\
\text { Acanthacées }\end{array}$ & $\begin{array}{l}\text { Bengal } \\
\text { Trumpet }\end{array}$ & India & liana & $\begin{array}{l}\text { Humid and } \\
\text { moderately humid }\end{array}$ & $\begin{array}{l}\text { Bushy, pre-forest, secondary } \\
\text { forest, large mesophile and } \\
\text { hygrophile forest gaps }\end{array}$ & $\begin{array}{l}\text { Zoochore? } \\
\text { (Explosive } \\
\text { dissemination) }\end{array}$ \\
\hline
\end{tabular}

These data are from research or biocenological observations (P. JOSEPH)

\section{Materials and Methods}

\subsection{Physical Context}

Floristic surveys were performed at known sites of Funtumia elastica (Figure 4). These sites of varied topography (steep slopes, riparian terraces) are specified by mesological parameters such as temperature, pluviosity, nebulosity, evapotranspiration, insolation (Note 1), etc. (Table 2). The vegetal formations that develop there are essentially conditioned by the pluviometry, which is a major bioclimatic factor in the Lesser Antilles. They are therefore influenced by sub-humid humid (Case Navire: 13 stations, Figure 4) and humid [(Camp de Balata (3 stations, Figure 4) and Morne Surey (one station, Figure 4)] bioclimates. The ecosystemic potentialities associated with these bioclimates are respectively tropical seasonal evergreen type forest and ombrophile sub-montane tropical lower horizon forest, some facies of which may resemble the tropical seasonal ombro-evergreen forest ecotone. At present, the research stations are of secondary formations and belong to several stages of the floristic succession: a poorly structured young secondary forest stage (two poorly individualised strata: canopy with low density and non-imbricated crowns), secondary structured forest stage (three well defined strata: canopy with fairly dense and non-imbricated crowns), pre-forest stage (more or less dense bushy matrix from which trees emerge at various stages of their morphogenetic development) and bushy stage. These dynamic stages correspond to different degrees of opening of the canopy in relation to the insolation of the intra-forest environment and therefore to multiple intra-vegetation environments. 


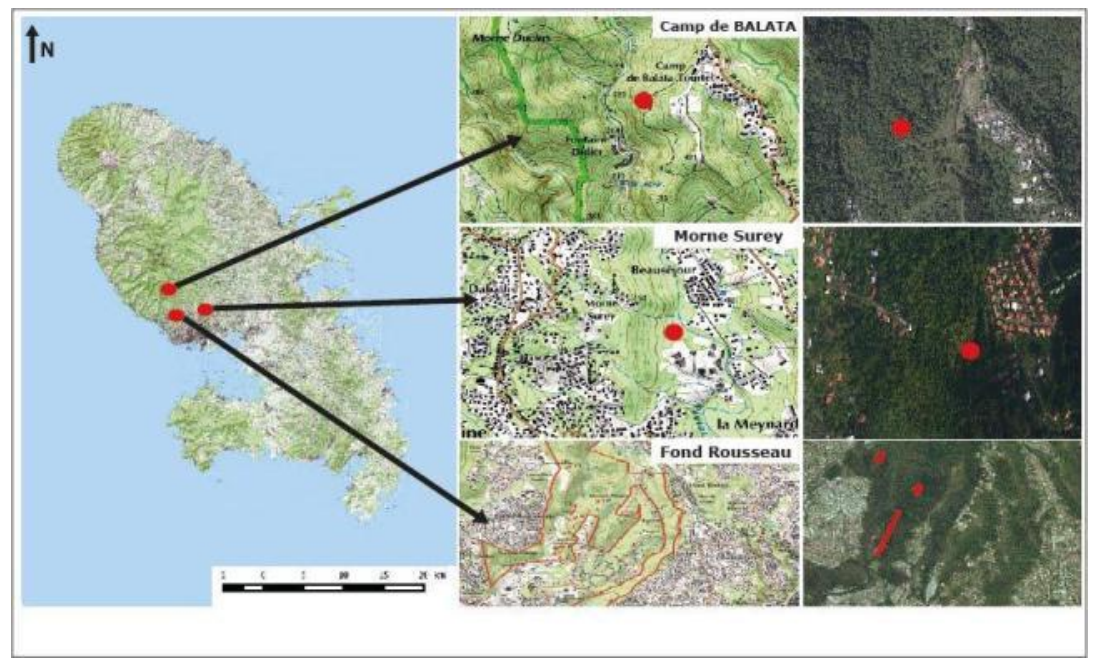

Figure 4. Geographical location of the floristic inventory stations

Table 2. Some characteristics of the floristic survey stations

\begin{tabular}{|c|c|c|c|c|c|c|c|c|}
\hline Stations & $\begin{array}{l}\begin{array}{l}\text { Area } \\
\text { surveyed } \\
\left(\mathrm{m}^{2}\right)\end{array} \\
\end{array}$ & Bioclimates & $\begin{array}{l}\text { Insolation } \\
\text { (number of } \\
\text { hours) }\end{array}$ & $\begin{array}{l}\text { Average } \\
\text { temperature }\end{array}$ & $\begin{array}{l}\text { Humidity } \\
(\%) / \\
24 \mathrm{~h} \\
\end{array}$ & $\begin{array}{l}\text { Annual } \\
\text { rainfall } \\
(\mathrm{mm}) \\
\end{array}$ & $\begin{array}{l}\text { Evapotranspiration } \\
(\mathrm{mm})\end{array}$ & Physionomic types \\
\hline $\begin{array}{l}\text { FR1 (Riparian } \\
\text { terrace) }\end{array}$ & $765 \mathrm{~m}^{2}$ & $\begin{array}{l}\text { Subhumid } \\
\text { humid }\end{array}$ & 2851.7 & 26 & 50 à 90 & 1705 & 1725 & Forest formation \\
\hline $\begin{array}{l}\text { FR2 (Riparian } \\
\text { terrace) }\end{array}$ & $825 \mathrm{~m}^{2}$ & $\begin{array}{l}\text { Subhumid } \\
\text { humid }\end{array}$ & 2851.7 & 26 & 50 à 90 & 1705 & 1725 & Forest formation \\
\hline $\begin{array}{l}\text { FR3 (Average } \\
\text { slope) }\end{array}$ & $400 \mathrm{~m}^{2}$ & $\begin{array}{l}\text { Subhumid } \\
\text { dry }\end{array}$ & 2851.7 & 26 & 50 à 90 & 1705 & 1725 & Forest formation \\
\hline $\begin{array}{l}\text { FR4 (Average } \\
\text { slope) }\end{array}$ & $450 \mathrm{~m}^{2}$ & $\begin{array}{l}\text { Subhumid } \\
\text { dry }\end{array}$ & 2851.7 & 26 & 50 à 90 & 1705 & 1725 & $\begin{array}{l}\text { Mature bushy } \\
\text { formation }\end{array}$ \\
\hline $\begin{array}{l}\text { FR5 (Average } \\
\text { slope) }\end{array}$ & $400 \mathrm{~m}^{2}$ & $\begin{array}{l}\text { Subhumid } \\
\text { dry }\end{array}$ & 2851.7 & 26 & 50 à 90 & 1705 & 1725 & $\begin{array}{l}\text { Mature bushy } \\
\text { formation }\end{array}$ \\
\hline $\begin{array}{l}\text { FR6(Riparian } \\
\text { terrace) }\end{array}$ & $1000 \mathrm{~m}^{2}$ & $\begin{array}{l}\text { Subhumid } \\
\text { humid }\end{array}$ & 2851.7 & 26 & 50 à 90 & 1705 & 1725 & Forest formation \\
\hline $\begin{array}{l}\text { FR7(Riparian } \\
\text { terrace) }\end{array}$ & $450 \mathrm{~m}^{2}$ & $\begin{array}{l}\text { Subhumid } \\
\text { humid }\end{array}$ & 2851.7 & 26 & 50 à 90 & 1705 & 1725 & $\begin{array}{l}\text { Forest and } \\
\text { pre-forest bushy } \\
\text { units }\end{array}$ \\
\hline $\begin{array}{l}\text { FR 8(Riparian } \\
\text { terrace) }\end{array}$ & $600 \mathrm{~m}^{2}$ & $\begin{array}{l}\text { Subhumid } \\
\text { humid }\end{array}$ & 2851.7 & 26 & 50 à 90 & 1705 & 1725 & $\begin{array}{l}\text { Mature bushy } \\
\text { formation }\end{array}$ \\
\hline FR 9 & $800 \mathrm{~m}^{2}$ & $\begin{array}{l}\text { Subhumid } \\
\text { dry }\end{array}$ & 2851.7 & 26 & 50 à 90 & 1705 & 1725 & $\begin{array}{l}\text { Mature bushy } \\
\text { formation }\end{array}$ \\
\hline FR10 & $800 \mathrm{~m}^{2}$ & $\begin{array}{l}\text { Subhumid } \\
\text { humid }\end{array}$ & 2851.7 & 26 & 50 à 90 & 1705 & 1725 & Forest formation \\
\hline FR 11 & $500 \mathrm{~m}^{2}$ & $\begin{array}{l}\text { Subhumid } \\
\text { dry }\end{array}$ & 2851.7 & 26 & 50 à 90 & 1705 & 1725 & Forest formation \\
\hline FR12 & $500 \mathrm{~m}^{2}$ & $\begin{array}{l}\text { Subhumid } \\
\text { humid }\end{array}$ & 2851.7 & 26 & 50 à 90 & 1705 & 1725 & Forest formation \\
\hline FR 13 & $920 \mathrm{~m}^{2}$ & $\begin{array}{l}\text { Subhumid } \\
\text { humid }\end{array}$ & 2851.7 & 26 & 50 à 90 & 1705 & 1725 & Forest formation \\
\hline FR PJ & $1000 \mathrm{~m}^{2}$ & $\begin{array}{l}\text { Subhumid } \\
\text { humid }\end{array}$ & 2851.7 & 26 & 50 à 90 & 1705 & 1725 & Forest formation \\
\hline $\begin{array}{l}\text { CB 1(Average } \\
\text { slope) }\end{array}$ & $480 \mathrm{~m}^{2}$ & Humid & 2600 & 26,6 & 50 à 90 & 2406,2 & 1625 & Forest formation \\
\hline $\begin{array}{l}\text { CB } 2 \text { (Average } \\
\text { slope) }\end{array}$ & $675 \mathrm{~m}^{2}$ & Humid & 2600 & 26,6 & 50 à 90 & 2406,2 & 1625 & Forest formation \\
\hline $\begin{array}{l}\text { CB PJ (Average } \\
\text { slope) }\end{array}$ & $1000 \mathrm{~m}^{2}$ & Humid & 2600 & 26,6 & 50 à 90 & 2406,2 & 1625 & Forest formation \\
\hline $\begin{array}{l}\text { MS (Riparian } \\
\text { terrace) }\end{array}$ & $450 \mathrm{~m}^{2}$ & Humid & 2904.8 & 26,4 & 50 à 90 & 1750.6 & 1700 & Forest formation \\
\hline
\end{tabular}




\subsection{Main Botanical Characteristics of Funtumia Elastica}

The species Funtumia elastica (Preuss) Stapf is native to tropical Africa and was long ago introduced to some English-speaking Lesser Antilles as a source of latex. In descending phylogenetic hierarchical order, it belongs respectively to the Tracheobionta Sub-kingdom (vascular plants), the Spermaphytes Superdivision (seed plants), the Magnoliopsida Division (the dicotyledons), the Gentianales order, the Apocynaceae Family and the Funtumia genus. This taxon of tree physiognomy type in adulthood is little known in the French Antilles. It was introduced between 1896 and 1897 and would be affine to humid and moderately humid environments (Howard, 1988, Photos 1 and 2).

The leaves of Funtumia elastica, which often form plagiotropic twigs, are simple, opposite, lanceolate and petiolate (Figure 5, Photo 2). The multiple flowers are gathered in axillary cymes and produce, after fertilisation, fruits which consist of two ligneous follicles approximately $15 \mathrm{~cm}$ long and 5 to $7 \mathrm{~cm}$ wide (Figure 5). The structure of the egret seeds encourages a long atmospheric lifetime, resulting in long-range anemochoric dissemination (Figure 5). The largest diameters and heights of adult individuals in Martinique are typically between 30 to $50 \mathrm{~cm}$ and 30 to $35 \mathrm{~m}$ respectively (Photo 1 ).

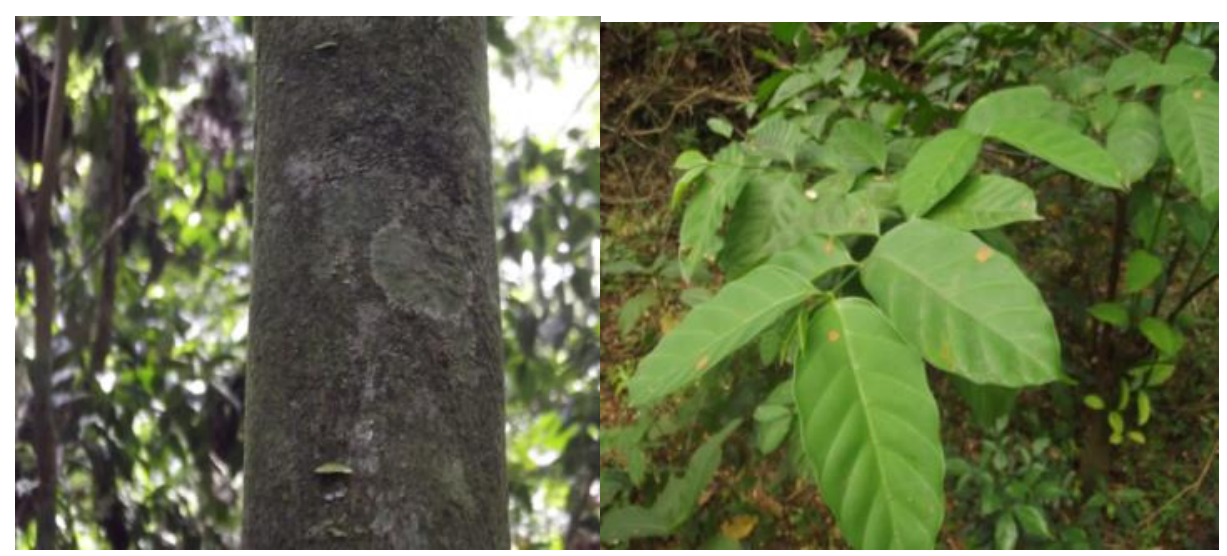

Photos 1 and 2. Trunk and leaves of Funtumia elastica
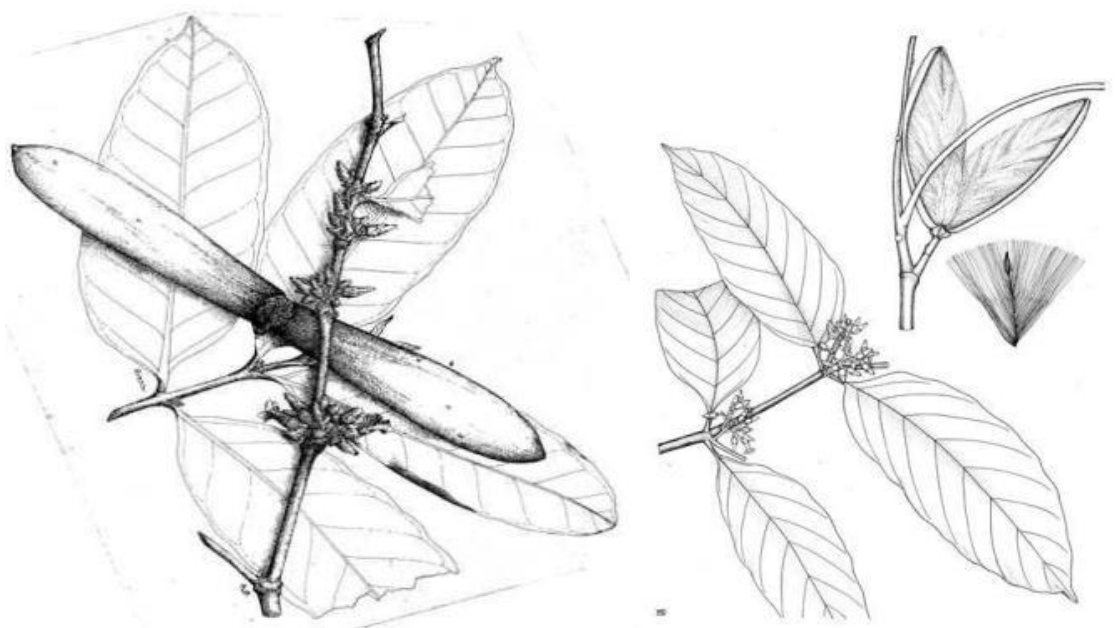

Figure 5. Main features of the phyllotaxis and reproductive systems

Source: Pacific Island Ecosystems at Risk -http://128.2.21.109/HIBD-Image/DBART-06725/USD-2000/6725.2083

\subsection{Data Collection and Analysis}

The method chosen for this study falls within macroecology. The objective is to characterise the structural and functional dimensions of the different floristic stations and thus to elucidate the ecological profile of Funtumia elastica. Using transects subdivided into quadrats and depending on the minimum basal area (between 400 and $1000 \mathrm{~m}^{2}$ ) (Note 2), we generated data that are both ecological and floristic descriptors (Figure 6): species, numbers of individuals from vegetal species populations, from regenerations to mature specimens 
(biodemographic aspect), diametric classes (sections measured at $1.33 \mathrm{~m}$ above ground in accordance with international standards), height classes.

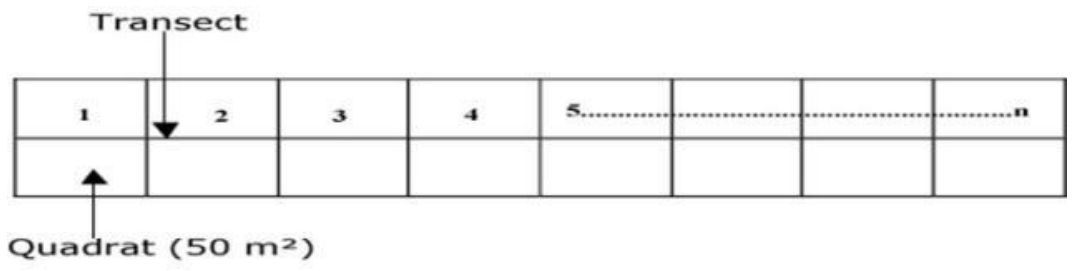

Figure 6. Unit of floristic surveys

These features enabled us to:

- assess the distribution of the sections of the individuals, the architecture of the formations (height distribution) and the characteristics of the canopies,

- evaluate phytomasses or biovolumes using the basal area, which corresponds to the sum of the areas of the circles that constitute the sections measured at 1.33 metres from the ground.

- learn the distribution of the species between the transect quadrats and between stations using the Index of Distribution which has the following formula: $\mathrm{Id}=\mathrm{fr} \times \mathrm{d}$ [fr being the relative frequency and $\mathrm{d}(\mathrm{nb} / \mathrm{sr})$ the density corresponding to the number of individuals of the species in question (nb) divided by the area surveyed $(\mathrm{sr})]$. Id is an index characterising the sociability class of the individuals of various species. These can be dispersed or gregarious.

- learn about the relative dominance of the vegetal species in relation to each other between the quadrats of the stations and between the stations by means of the Index of Dominance (ID). ID $=\mathrm{Id} \times \mathrm{St}$ (St: Basal area). Although regressive, the floristic units of the survey areas are little affected by anthropisation. As a result, they can be considered homogeneous in their evolution phase. This is apart from the windfalls, which from the point of view of the basal area of the various stations are marginal. In this context, the ID is sufficiently intelligible with regard to the competitive abilities of the taxa.

Comparison between stations and between species populations was possible by dint of Factorial Analyses of Correspondences (CFA) and Ascending Hierarchical Classification (AMP) (Note 3).

\section{Results}

\subsection{Stational Differentiation Using Factorial Analyses of Correspondence (AFC) and Ascending Hierarchical Classification (CHA)}

Based on the demography of the species of all the stations, the Factorial Analysis of Correspondence (AFC) allowed us to discriminate between the survey stations (18) and between the affine species (188) of the latter. We have retained only the results from axes 1 and 2 which combine the inertia maximum which is $29.67 \%$ (Figure 7). Axis 1 contrasts the environments with specific mesological characteristics while axis 2 differentiates distinctively between stations belonging to topographic facies and to particular levels of ecosystemic evolution (Figure 7). The majority of the Group C stations (FR1, FR2, FR6, FR7, FR8, FR12, FR13 \& FRPJ) are located on riparian terraces and correspond to mesophilic or even meso-hygrophilic environments due to significant confinement (Figure 7). In this same group C station 10, which is further uphill (inland), hosts a formation which is also hygro-mesophilic but on a slope. In the CB1, CB and CBJP (group A) sloping stations, the eco-climatic conditions are typical of tropical hygro-mesophilic or even tropical ombro-evergreen seasonal environments (Figure 6). The MS station is located between groups A and C and is colonised by a hygro-mesophilic floristic group on alluvial terrace. Conversely, in group B the stations consist purely of xerophilic phytocenoses (Figure $7)$. 


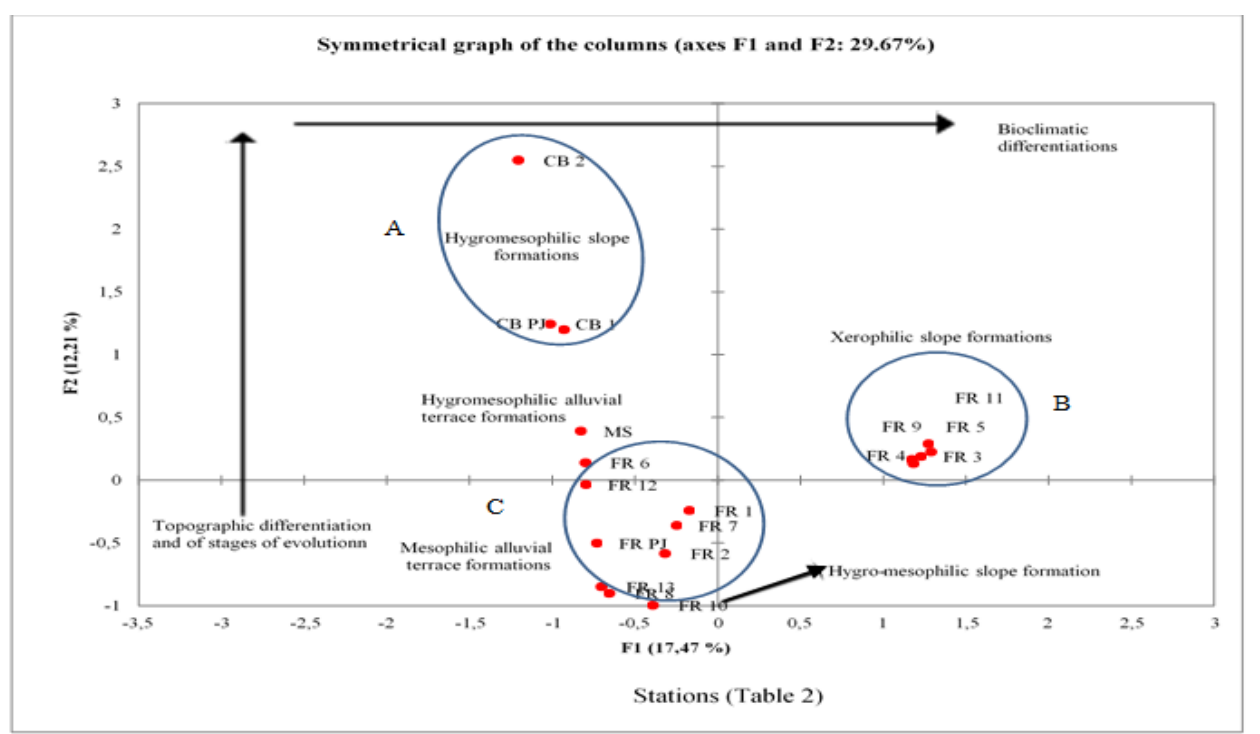

Figure 7. Discrimination between biotopes and between ecosystemic evolution stages (all stations, see Table 2)

An AFC carried out based on a contingency table of populations of 155 species from 13 stations (groups B and C) located at the locality of Fond ROUSSSEAU (FR stations, Figures $4 \& 8 \mathrm{a}$ ) also shows in a tangible way a differentiation of the biotopes (axis F1) and a gradient of evolution (axis F2) (Figure 8b). The FR1, FR2 \& FR6 stations are among the most regressive of the mesophilic environments and are composed of bushy matrix eco-units pegged with relictual (Note 4) mature trees with significant biovolumes (particularly in the FR1 \& FR2 stations). The stations associated with xerophilic environments are colonised by phytocenoses which are located between the bushy or pre-forest stages (FR3, FR4 \& FR5) and young unstructured forest (FR9 and FR11, no defined stratification, Figure $8 b$ ).

From the AFCs, it follows that the floristic survey stations CB1, CB2, CBJP and MS belong to the forest stage. Along with FR10, these stations are totally conditioned by the subhumid humid (FR10) and humid (CB1, CB, CBJP and MS) bioclimate whereas the mesophilic character of stations FR1, FR2, FR6, FR7, FR8, FR12, FR13 and FRJP results from a phenomenon of topographical correction of macro-climatic factors. In fact, at the level of the riparian terraces of confined valleys, the relatively higher hygrometry is due to the influence of the watercourse and the lower average annual insolation. Added to these elements is a greater depth of soil resulting from colluviation stemming from the erosion of the adjacent slopes. Of course, as well as the natural colluviation there has also been anthropogenic colluviation linked to past deforestation or selective harvesting.

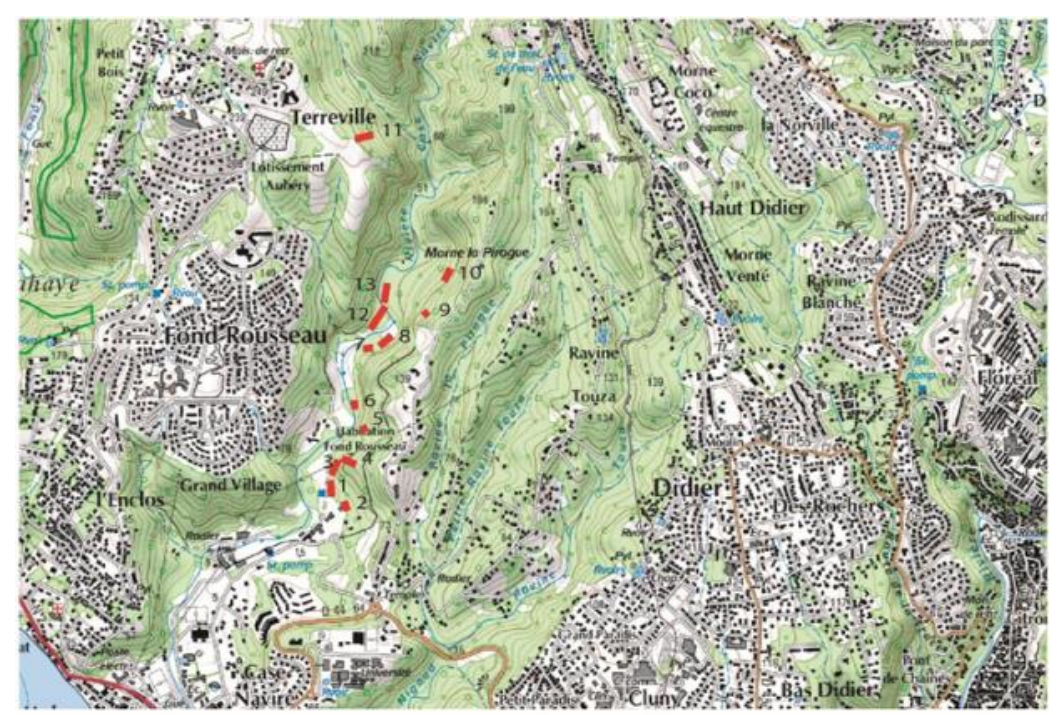

Figure 8a. Floristic survey stations at the locality of Fond ROUSSEAU (see Figure 4) 


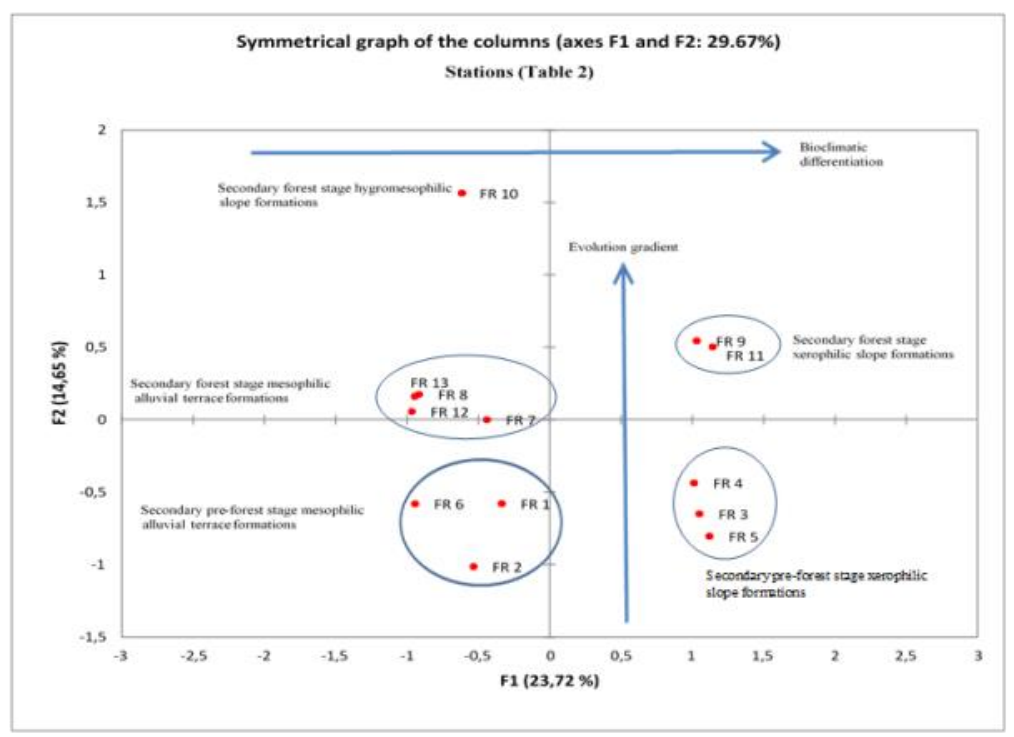

Figure 8b. Mesological Differentiations and Evolutionary Stage Differentiations (Stations FOND ROUSSEAU, see Figure 4)

Figures 7 and $8 \mathrm{~b}$ show two important features of the ecology of Funtumia elastica. Firstly, this species develops in humid biotopes (humid and subhumid humid bioclimates) and is therefore not present in dry environments (FR3, FR4, FR5, FR9 and FR11 stations). Secondly, it is affine to successional stages ranging from pre-forest to advanced or late forest in both the forest matrix and the gaps. These two features identify in a global manner the main features of the eco-climatic profile of Funtumia elastica. Stations with a xeric tendency have therefore been removed from the contingency table because they are not suitable for installation and demographic growth. An Ascending Hierarchical Classification (CHA) has made it possible to single out two groups which correspond respectively to the hygro-mesophilic (A) and mesophilic (B) mesophilic stations, whatever the topographic facies (riparian terrace or slope, Figure 9). The degree of stational similarity in cluster A or cluster B is quite low and variable (Figure 9), indicating that Funtumia elastica is present in multiple floristic and populational combinations at varying levels of ecosystemic evolution. This species consequently presents a certain ubiquity with regard to the stations studied.

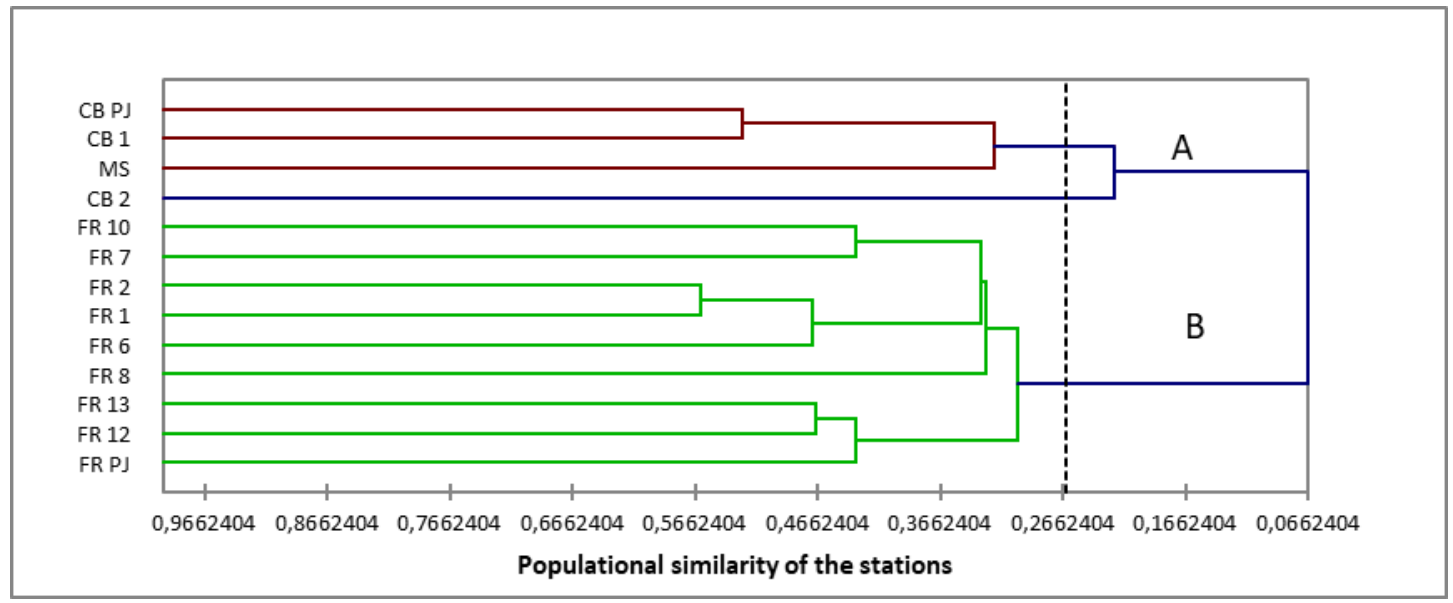

Figure 9. Classification of the Funtumia elastica stations based on their populational similarity (see Table 2)

\subsection{Prominence of Funtumia Elastica per Station and for the Set of all the Stations}

The ID (Index of Dominance) (Note 5) calculated for all the species of the stations where Funtumia elastica is present makes it possible to highlight the predominant corteges (Table 3). In fact, the prominence of the populations (density and distribution) and their total biomasses (estimated using basal areas) gives a small group 
of species an ecological dominance. Although Funtumia elastica is present in all the stations, it is only part of the dominant cortege in 11 stations (Table 3). In the FR2 and FR8 stations, the populations of this species are reduced to poorly distributed regenerations and isolated adult individuals in a few quadrats: the overall set corresponding to a very low epigeous biomass. It should also be noted that the Funtumia elastica does not occupy the same position of prominence in the dominant floristic corteges of the stations (Table 3). This is to be related to its ecology (Table 3). On the other hand, for the totality of the stations (18 areas of floristic surveys), Funtumia elastica has a very high index of dominance (ID $=0.255$, Table 4 ) relative to other species. In comparison with other species, the latter (the ID of Funtumia elastica) results from a large number of individuals $(\mathrm{Ni}=1350)$ and a relative frequency $(\mathrm{Fr})$ of $72 \%$ and total basal area $\left(\mathrm{ST}=3.402 \mathrm{~m}^{2}\right)$ which are comparatively high. These descriptors $(\mathrm{Ni}, \mathrm{Fr})$ give this taxon (Funtumia elastica) the greatest density $(\mathrm{d}=0.1304$ individuals $\left./ \mathrm{m}^{2}\right)$ and a good distribution $(\mathrm{Id}=0.075)$ in the stations (between the quadrats) and between the stations (Table 4).

Table 3. Main ecological characteristics of stations with Funtumia elastica

\begin{tabular}{|c|c|c|c|}
\hline Stations & Formation types & Stages of evolution & Floristic dominance (ID) \\
\hline FR1 & $\begin{array}{l}\text { Tropical seasonal evergreen } \\
\text { formation }\end{array}$ & $\begin{array}{l}\text { barely structured secondary } \\
\text { forest (two defined strata) }\end{array}$ & $\begin{array}{l}\text { Funtumia elastica }(0.0077) / \text { Samanea saman }(0.0074) / \text { Piper } \\
\text { amalago }(0.0072) / \text { Inga ingoides }(0.0044) / \text { Cordia sulcata } \\
(0.0014)\end{array}$ \\
\hline FR2 & $\begin{array}{l}\text { Tropical seasonal evergreen } \\
\text { formation }\end{array}$ & $\begin{array}{l}\text { barely structured secondary } \\
\text { forest (two defined strata) }\end{array}$ & Cordia sulcata $(0.033) /$ Inga ingoides $(0.0025)$ \\
\hline FR6 & $\begin{array}{l}\text { Seasonal evergreen type } \\
\text { formation }\end{array}$ & secondary forest & Funtumia elastica $(0.112) /$ Inga ingoides $(0.0225)$ \\
\hline FR7 & Mixed formation & $\begin{array}{l}\text { eco-units corresponding to the } \\
\text { bushy, pre-forest and secondary } \\
\text { forest stages }\end{array}$ & $\begin{array}{l}\text { Myrcia splendens }(0.0315) / \text { Inga ingoides }(0.0176) / \text { Funtumia } \\
\text { elastica }(0.01)\end{array}$ \\
\hline FR8 & Mixed formation & $\begin{array}{l}\text { young bushy, pre-forest and } \\
\text { forest units }\end{array}$ & $\begin{array}{l}\text { Myrcia splendens }(0.132) / \text { Simarouba amara }(0.1) / \text { Andira } \\
\text { inermis }(0.05) / \text { Sapium caribaeum }(0.03)\end{array}$ \\
\hline FR10 & $\begin{array}{l}\text { Tropical seasonal evergreen } \\
\text { formation }\end{array}$ & secondary forest & $\begin{array}{l}\text { Cupania americana }(0.031) / \text { Simarouba amara } \\
(0.024) \text { Sapium caribaeum }(0.01) / \text { Ceiba pentandra } \\
(0.0064) / \text { Tabernaemontana citrifolia }(0.0045) / F u n t u m i a \\
\text { elastica } 0.004)\end{array}$ \\
\hline FR12 & $\begin{array}{l}\text { Tropical seasonal evergreen } \\
\text { formation }\end{array}$ & secondary forest & $\begin{array}{l}\text { Simarouba amara }(0.05) / \text { Funtumia elastica }(0.04) / \text { Inga } \\
\text { ingoides }(0.021) / \text { Sapium caribaeum }(0.014)\end{array}$ \\
\hline FR13 & $\begin{array}{l}\text { Tropical seasonal } \\
\text { ombro-evergreen } \\
\text { formations: ecotone }\end{array}$ & structured secondary forest stage & $\begin{array}{l}\text { Simarouba amara (0. 04)/Myrcia splendens }(0.02) / \text { Cordia } \\
\text { alliodora }(0.014)\end{array}$ \\
\hline FRJP & $\begin{array}{l}\text { Tropical seasonal } \\
\text { ombro-evergreen } \\
\text { formations: ecotone }\end{array}$ & structured secondary forest stage & $\begin{array}{l}\text { Simarouba amara }(0.022) / \text { Inga ingoides }(0.01) / \text { Funtumia } \\
\text { elastica }(0.0055) / \text { Artocarpus altilis }(0.0044)\end{array}$ \\
\hline CB1 & $\begin{array}{l}\text { Tropical mountain } \\
\text { ombrophile formation }\end{array}$ & structured secondary forest stage & Funtumia elastica (0.193) / Quararibea turbinata (0.01) \\
\hline CB2 & $\begin{array}{l}\text { Tropical mountain } \\
\text { ombrophile formation }\end{array}$ & structured secondary forest stage & Castilla elastica (0.35)/Funtumia elastica (0.17) \\
\hline CBPJ & $\begin{array}{l}\text { Tropical mountain } \\
\text { ombrophile formation }\end{array}$ & structured secondary forest stage & $\begin{array}{l}\text { Funtumia elastica (0.152)/Myrcia fallax (0.016)/Guazuma } \\
\text { ulmifolia (0.013) }\end{array}$ \\
\hline MS & $\begin{array}{l}\text { Tropical mountain } \\
\text { ombrophile formation }\end{array}$ & secondary forest stage & Funtumia elastica $(0.022) /$ Piper dilatatum (0.012) \\
\hline
\end{tabular}


Table 4. Values of descriptors of main species for all stations

\begin{tabular}{|c|c|c|c|c|c|c|c|c|}
\hline Species & Families & $\begin{array}{l}\text { Absolute } \\
\text { frequency } \\
\text { (Fa) }\end{array}$ & $\begin{array}{l}\text { Relative } \\
\text { frequency } \\
\text { (Fr) }\end{array}$ & $\begin{array}{c}\text { Number of } \\
\text { individuals per } \\
\text { species excluding } \\
\text { regeneration }(\mathrm{Ni})\end{array}$ & $\begin{array}{l}\text { Density (d: number } \\
\text { of individuals } / \mathrm{m}^{2} \text { ) }\end{array}$ & $\begin{array}{l}\text { Index of } \\
\text { distribution } \\
\text { (Id) }\end{array}$ & $\begin{array}{l}\text { Total basal area } \\
\text { per species (ST } \\
\left.\text { in } \mathrm{m}^{2}\right)\end{array}$ & $\begin{array}{c}\text { Index of } \\
\text { dominance } \\
\text { (ID) }\end{array}$ \\
\hline $\begin{array}{l}\text { Funtumia } \\
\text { elastica } \\
\text { Inga }\end{array}$ & Apocynaceae & 13 & $72 \%$ & 1350 & 0.1034 & 0.075 & 3.402 & 0.255 \\
\hline $\begin{array}{l}\text { ingoides } \\
\text { Myrcia }\end{array}$ & Mimosaceae & 16 & $89 \%$ & 364 & 0.028 & 0.025 & 6.055 & 0.151 \\
\hline $\begin{array}{l}\text { splendens } \\
\text { Simarouba }\end{array}$ & Myrtaceae & 15 & $83 \%$ & 820 & 0.0631 & 0.0526 & 1.723 & 0.090 \\
\hline $\begin{array}{l}\text { amara } \\
\text { Eugenia }\end{array}$ & Simaroubaceae & 11 & $61 \%$ & 213 & 0.0164 & 0.010 & 7.854 & 0.079 \\
\hline $\begin{array}{l}\text { monticola } \\
\text { Pimenta }\end{array}$ & Myrtaceae & 15 & $83 \%$ & 922 & 0.071 & 0.06 & 1.205 & 0.0712 \\
\hline $\begin{array}{l}\text { racemosa } \\
\text { Pisonia }\end{array}$ & Myrtaceae & 13 & $72 \%$ & 312 & 0.024 & 0.0173 & 1.920 & 0.0333 \\
\hline $\begin{array}{l}\text { fragrans } \\
\text { Sapium }\end{array}$ & Nyctaginaceae & 17 & $94 \%$ & 244 & 0.019 & 0.018 & 1.35 & 0.024 \\
\hline $\begin{array}{l}\text { caribaeum } \\
\text { Coccoloba }\end{array}$ & Euphorbiaceae & 8 & $44 \%$ & 82 & 0.00631 & 0.0028 & 4.84 & 0.0136 \\
\hline $\begin{array}{l}\text { swartzii } \\
\text { Cordia }\end{array}$ & Polygonaceae & 13 & $72 \%$ & 151 & 0.012 & 0.0084 & 1.432 & 0.012 \\
\hline $\begin{array}{l}\text { sulcata } \\
\text { Calliandra }\end{array}$ & Boraginaceae & 11 & $61 \%$ & 166 & 0.012769231 & 0.0078 & 1.455 & 0.01136 \\
\hline tergemina & Mimosaceae & 5 & $28 \%$ & 493 & 0.037923077 & 0.0105342 & 0.9802688 & 0.010326336 \\
\hline
\end{tabular}

Table 5 and Figure 10 show a notable stational variability of Funtumia elastica with respect to structural descriptors such as Absolute Frequency (Fa), Relative Frequency (Fr), Number of Individuals (Ni), Density (d), Index of Distribution (Id), Basal Area (ST) and the Index of Dominance (ID). For each station and for the set of the stations, these descriptors provide information on the ecological aspects of Funtumia elastica and its competitive plasticity. The ID is a composite indicator constructed using the above indicators (ID $=\mathrm{Id} \times \mathrm{ST}$, Id $=$ $\mathrm{d} \times \mathrm{Fr}, \mathrm{Fr}=\mathrm{Fa}$ /number of quadrats of a transect). Its value indicates, with rather good significance, the colonising capacity of this species within stations and between stations. Funtumia elastica is present in $72 \%$ of the stations with the greatest number of individuals (1350). In comparison with other species, the result is a higher density $\left(0.1034\right.$ individuals $\left./ \mathrm{m}^{2}\right)$ and a greater distribution $(\mathrm{Id}=0.075)$. The basal area (Note 6) (TS) of this allochthonous species is related to its high density which, combined with its high distribution (Id), gives it a greater ecological dominance (ID, Table 4).

Table 5. Number of individuals and presence of Funtumia elastica in relation to the stations

\begin{tabular}{llll}
\hline Station (Table 2) & Absolute frequency $(\mathbf{F a})$ & Relative frequency $(\mathbf{F r})$ & Number of individuals (Ni) \\
\hline FR1 & 8 & $89 \%$ & 54 \\
FR2 & 7 & $64 \%$ & 16 \\
FR6 & 10 & $100 \%$ & 271 \\
FR7 & 9 & $100 \%$ & 63 \\
FR8 & 7 & $58 \%$ & 19 \\
FR10 & 8 & $100 \%$ & 33 \\
FR12 & 9 & $100 \%$ & 236 \\
FRJP & 9 & $90 \%$ & 23 \\
CB1 & 12 & $100 \%$ & 171 \\
CB2 & 9 & $100 \%$ & 169 \\
MS & 7 & $78 \%$ & 45 \\
FR13 & 7 & $78 \%$ & 23 \\
\hline
\end{tabular}




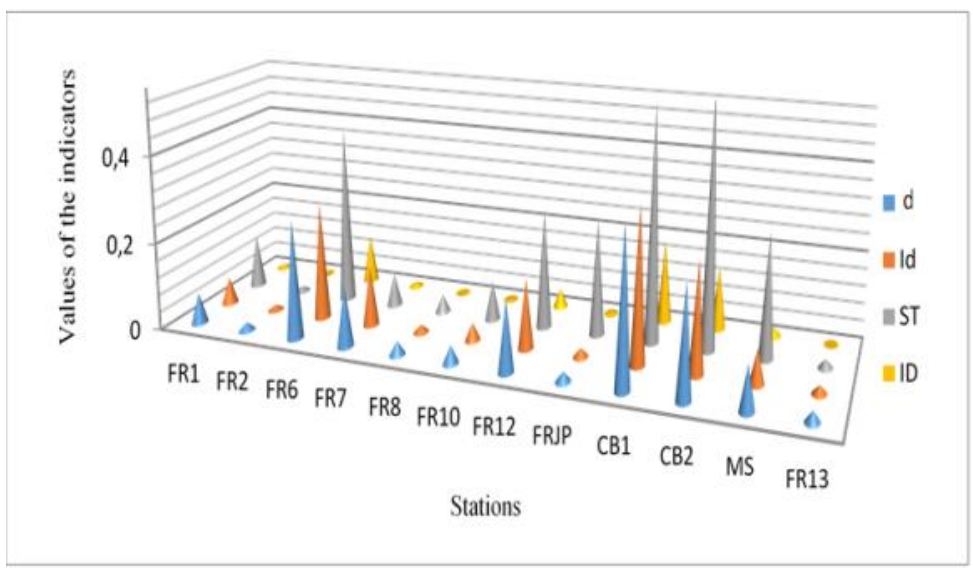

Figure 10. Some stational indices of Funtumia elastica (see Table 2)

\subsection{Distribution of Diameters and Stratigraphic Position in the Stations}

For each station, the sections of Funtumia elastica measured at $1.33 \mathrm{~m}$ show that the populations differ numerically. The $2.5 \mathrm{~cm}$ age group individuals are the most numerous, except for the CB1 and CB2 stations where the number of $5 \mathrm{~cm}$ class is relatively high (Figure 11). The stational populations of this species are not balanced because the mature specimens or specimens in the advanced phase of their morphogenetic development are few. They are often associated with seedlings and with regenerations that can become permanent. Despite the numbers, only the populations of CB1, CB2 and FRPJ stations seem to have a certain balance in the organisation of the classes of diameters ranging from $2.5 \mathrm{~cm}$ to $20 \mathrm{~cm}$ (Figure 11). The heights corroborate the observations concerning the diameters, since there is a relation, even a complex one, between diameters and heights. Indeed, the most prominent stratigraphic class is made up of 1-8 m. Despite the unequal number of individuals, only the FR10, FRPJ, CB1, CB2, CBPJ and MS stations appear to have a balanced stratigraphic profile (Figure 12). Whether regarding diameters or heights, the differences observed are to be related to the biocenotic characteristics of the survey stations (Figures 11 \& 12): in particular, their levels of evolution to which the specific factorial conditions correspond.

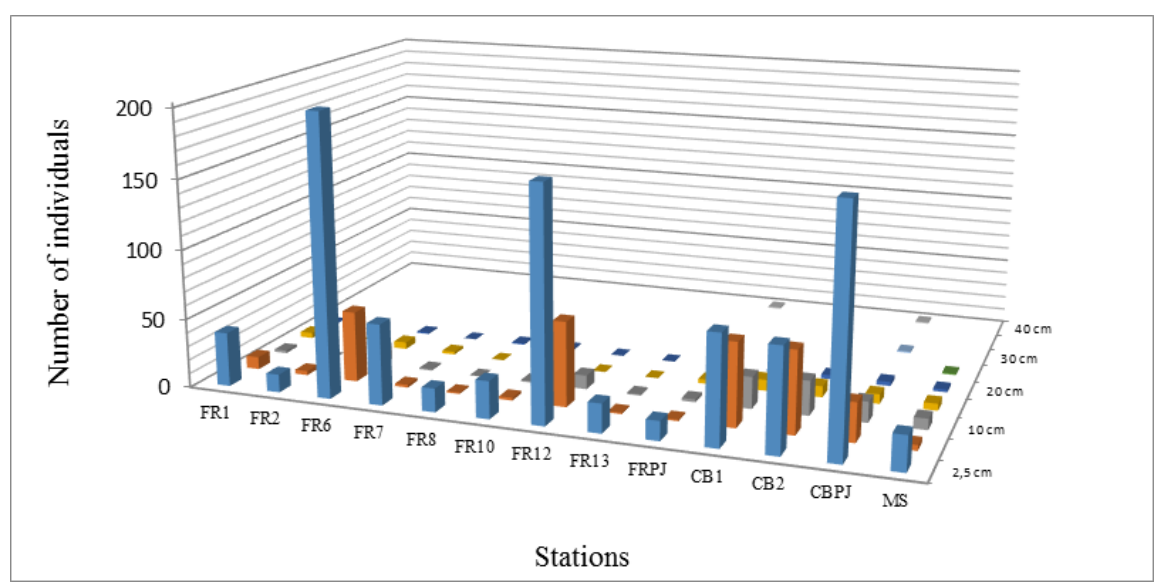

Figure 11. Distribution of the diameters of Funtumia elastica according to station (see Table 2) 


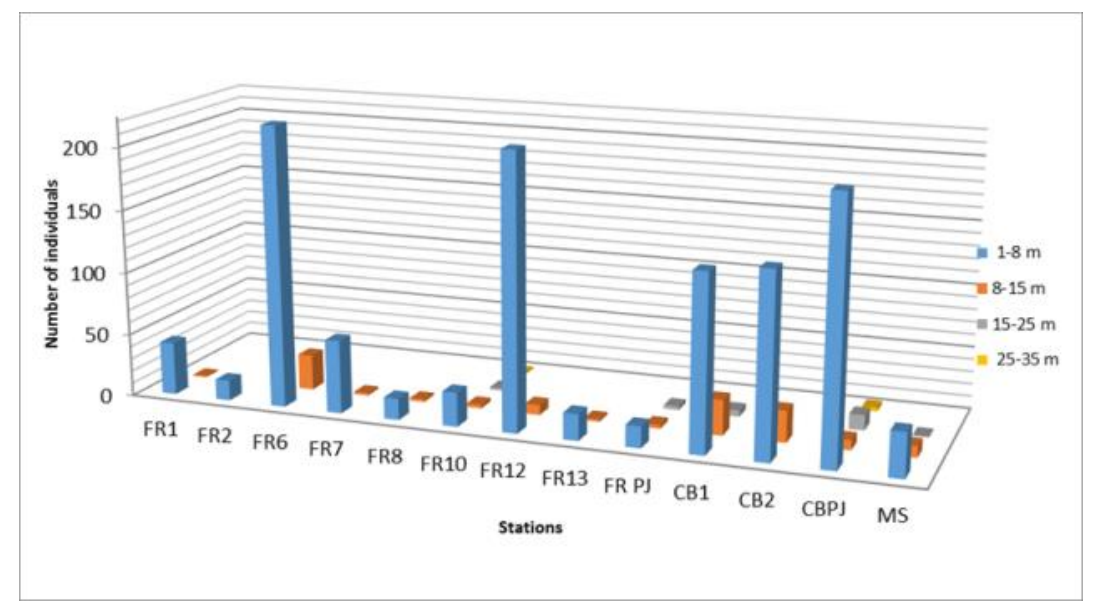

Figure 12. Distribution of the height classes of Funtumia elastica for each station (see Table 2)

\section{Discussion}

The AFCs and the Ascending Hierarchical Classification (CHA) based on similarity [Pearson's correlation coefficient, (Benesty, Chen \& Huang, 2008)] show that Funtumia elastica is affine to subhumid and humid biotopes. The latter are related to the macroclimate (CB1, CB2, MS, CBPJ and FR10 stations) or to topographic corrections inducing in particular in the bottoms of narrow dales or valleys of vegetation inversions (FR1, FR2, FR6, FR7, FR8, FR12, FR13 and FRPJ stations). Significantly, the AFCs highlight differences in the physiognomies of the phytocenoses colonising study stations corresponding to precise stages of the vegetal succession (Figure 13). This corroborates perfectly our observations on the ground. Indeed, Funtumia elastica may, with a variable demography, be part of the floristic combinations of the pre-forest or even bushy stage to the late secondary forest stage (mature forest). It appears to be more competitive in the pre-forest and young structured forest stages than in secondary forest. This is logical because in advanced forest formations the installation and expansion sites are much more specialised (the species are more antagonistic than competing). The mortality of Funtumia elastica is a feature to consider. In view of our observations, it varies according to age class (Figure 14).

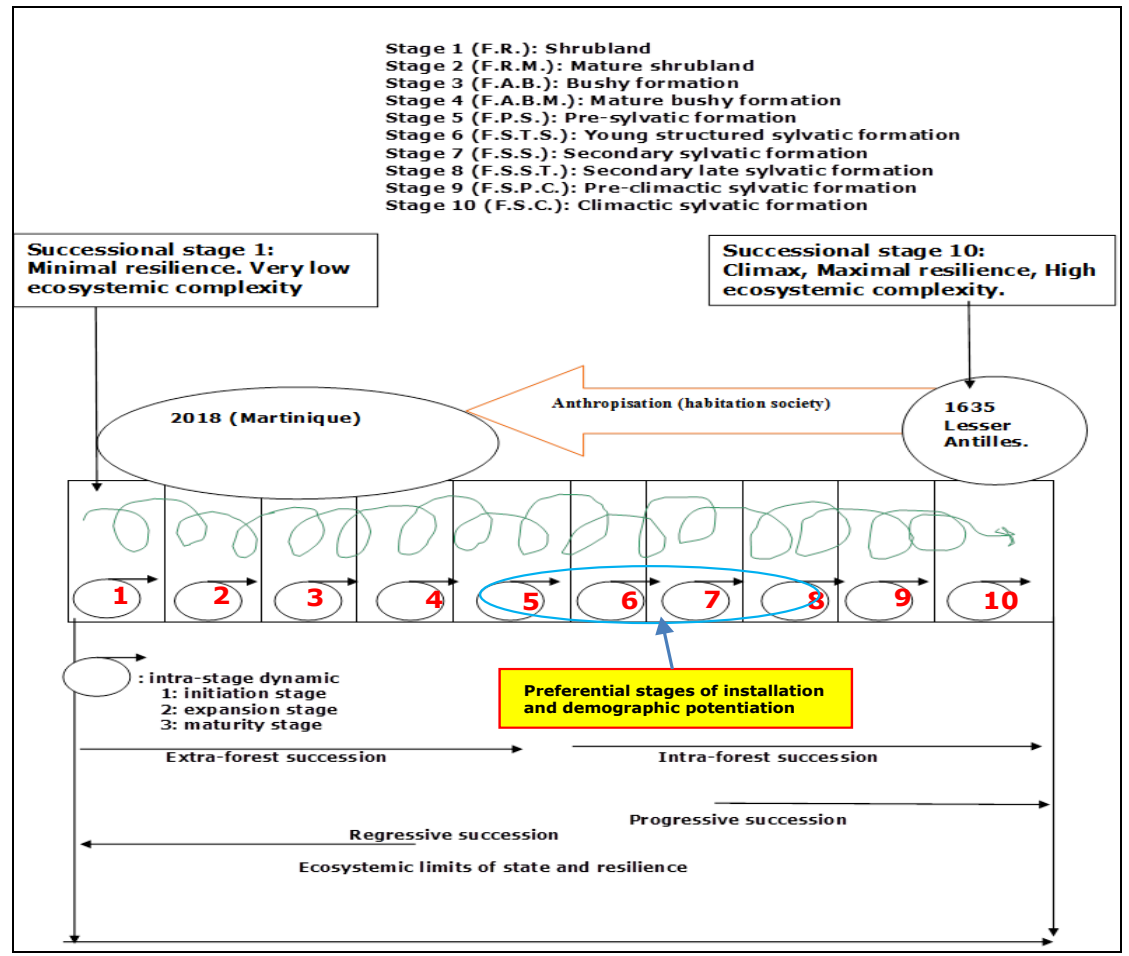

Figure 13. Likely behaviour of Funtumia elastica as regards vegetal succession 


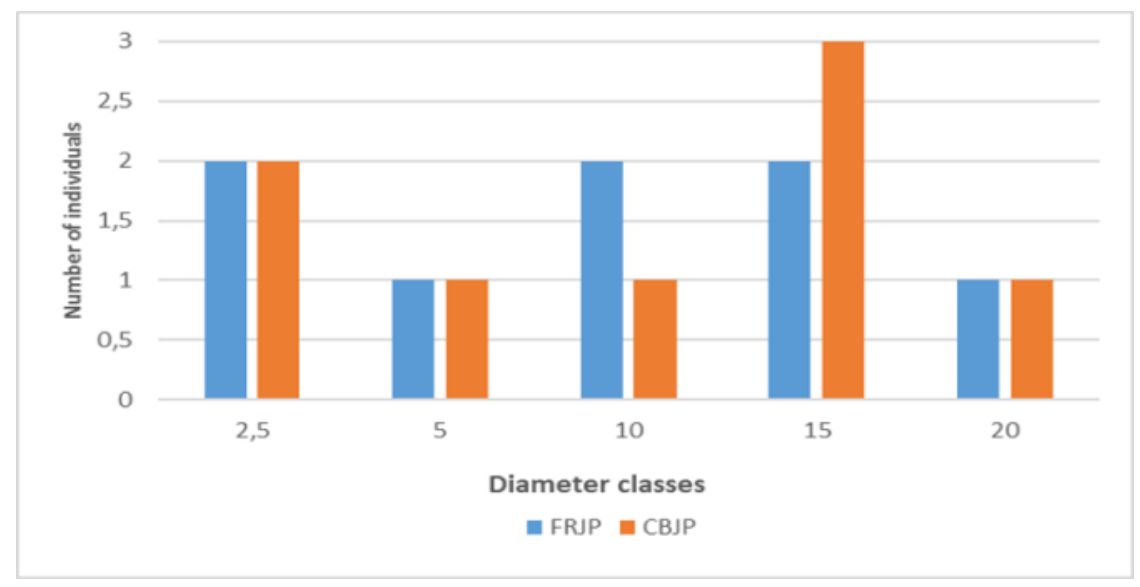

Figure 14. Natural mortality of Funtumia elastica according to diameter classes

In view of the first data recorded in this article, it is clear that Funtumia elastica is an extremely competitive species that in the future could become a dangerous vegetal pest for the autochthonous flora of the humid environments of Martinique and, more broadly, the Lesser Antilles. Figure 15 is a global, even rough, simulation of the likely installation environments of Funtumia elastica and was carried out by dint of a geographic information system (GIS) using the QGIS software (version 2.18.14). The main parameters used specific to the subhumid and humid bioclimates are pluviometry, temperature and altitude (Table 6).

Table 6. Zoning criteria

\begin{tabular}{ll}
\hline Descriptors & Value intervals \\
Altitude & 80 to 800 metres \\
Minimal annual average temperature & $20^{\circ}$ to $23^{\circ} \mathrm{C}$ \\
Maximal annual average temperature & $27^{\circ}$ to $30^{\circ} \mathrm{C}$ \\
Average annual rainfall & 2000 to $3000 \mathrm{~mm}$ \\
\hline
\end{tabular}

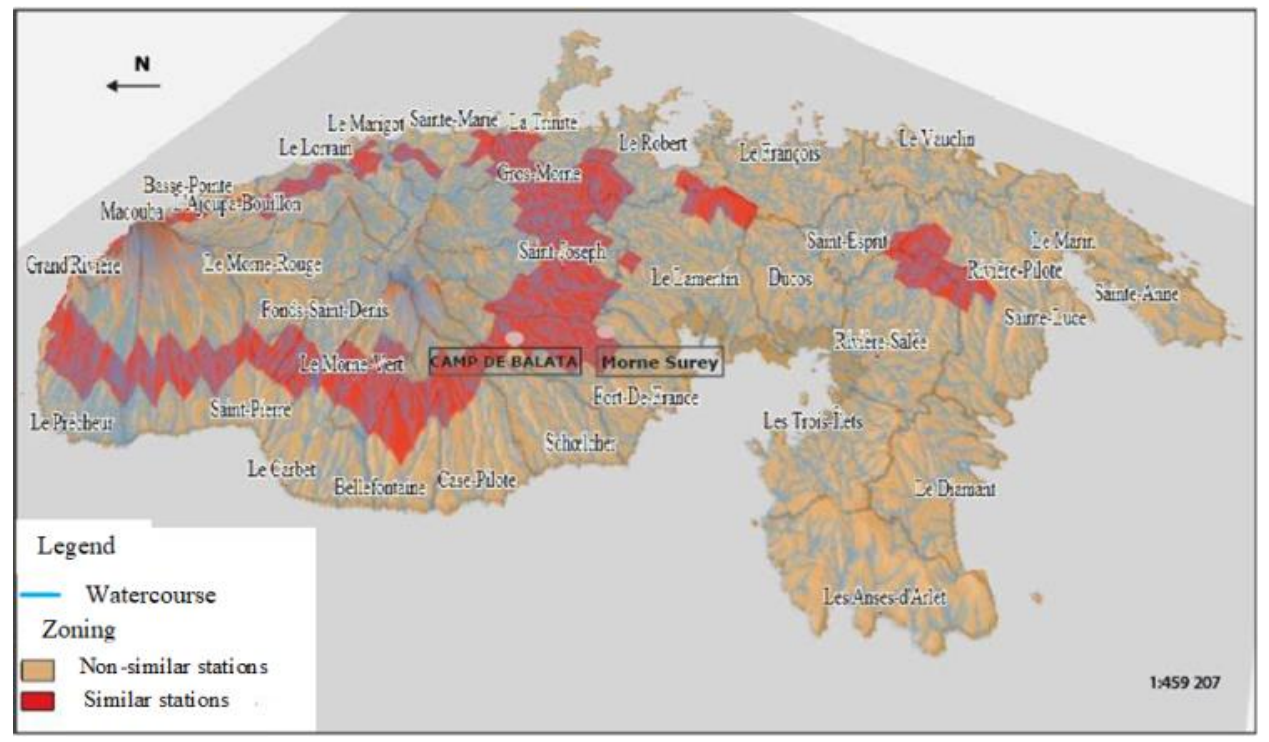

Figure 15. Likely installation environments of Funtumia Elastic

\section{Conclusion}

In the Lesser Antilles, among the mesological factors such as temperature, nebulosity, physical evaporation, evapotranspiration, humidity and insolation, pluviosity is the most significant because its altitudinal distribution defines the bioclimates and therefore the floristic staging. As a result, the annual rainfall pattern conditions the 
chorology of Funtumia elastica, which would be influenced by moderately humid and humid bioclimates. In general, the phenology (seed dispersal mode in particular) as well as the ecosystemic affinities (types of phytocenosis and dynamic stages) are significant parameters of the ecology of this introduced species. Given the potential for colonization of Funtumia elastica in humid and moderately humid biotopes, mechanical reduction seems to be the most effective and least expensive alternative.

\section{Acknowledgments}

The work that enabled the writing of this article presenting the first data on the ecological characteristics of Funtumia elastica in Martinique from the perspective of controlled management in terms of its biodemography was supported by the University of the Antilles through its administration and funded by the Territorial Collective of Martinique (CTM).

\section{References}

Bazzaz F. A. (1983). Characteristics of Populations in Relation to Disturbance in Natural and Man-Modified Ecosystems. In H. A. Mooney \& M. Godron (Eds.), Disturbance and Ecosystems. Ecological Studies (Analysis and Synthesis) (pp. 259-275), Springer, Berlin, Heidelberg. https://doi.org/10.1007/978-3-642-69137-9_17

Benesty, J., Chen, J., \& Huang, Y. (2008). On the importance of the Pearson correlation coefficient in noise reduction. IEEE Transactions on Audio, Speech, and Language Processing, 16(4), 757-765. https://doi.org/10.1109/TASL.2008.919072

Boudiaf, I., Baudoin, E., Sanguin, H., Beddiar, A., Thioulouse, J., Galiana, A., ... Duponnois, R. (2013). The exotic legume tree species, Acacia mearnsii, alters microbial soil functionalities and the early development of a native tree species, Quercus suber, in North Africa. Soil Biology and Biochemistry, 65, 172-179. https://doi.org/10.1016/j.soilbio.2013.05.003

Bunn, S. E., Davies, P. M., Kellaway, D. M., \& Prosser, I. P. (1998). Influence of invasive macrophytes on channel morphology and hydrology in an open tropical lowland stream, and potential control by riparian shading. Freshwater Biology, 39(1), 171-178. https://doi.org/10.1046/j.1365-2427.1998.00264.x

Butchart, S. H., Walpole, M., Collen, B., Van Strien, A., Scharlemann, J. P., Almond, R. E., ... Carpenter, K. E. (2010). Global biodiversity: indicators of recent declines. Science, 328(5982), 1164-1168. https://doi.org/10.1126/science.1187512

Chapin Iii, F. S., Zavaleta, E. S., Eviner, V. T., Naylor, R. L., Vitousek, P. M., Reynolds, H. L., ... Mack, M. C. (2000). Consequences of changing biodiversity. Nature, 405(6783), 234-242. https://doi.org/10.1038/35012241

Charles, H., \& Dukes, J. S. (2008). Impacts of Invasive Species on Ecosystem Services. In W. Nentwig (Eds.), Ecological Studies (pp. 217-237), Springer, Berlin, Heidelberg.

Cock, M. J. W. (1985). A Review of Biological Control of Pests in the Commonwealth Caribbean and Bermuda up to 1982. Commonwealth Agricultural Bureaux, Slough.

Corenblit, D., Steiger, J., Gurnell, A. M., \& Naiman, R. J. (2009). Plants intertwine fluvial landform dynamics with ecological succession and natural selection: a niche construction perspective for riparian systems. Global Ecology and Biogeography, 18(4), 507-520. https://doi.org/10.1111/j.1466-8238.2009.00461.x

Crawley, M. J. (2009). The structure of plant communities. Plant Ecology, Second Edition, 475-531. https://doi.org/10.1002/9781444313642.ch14

Daehler, C. C. (2006). Invasibility of tropical islands by introduced plants: partitioning the influence of isolation and propagule pressure. Preslia, 78(4), 389-404.

Dawson, W., Burslem, D. F., \& Hulme, P. E. (2009). Factors explaining alien plant invasion success in a tropical ecosystem differ at each stage of invasion. Journal of Ecology, 97(4), 657-66. https://doi.org/10.1111/j.1365-2745.2009.01519.x

Deblauwe, V., Couteron, P., Lejeune, O., Bogaert, J., \& Barbier, N. (2011). Environmental modulation of self organized periodic vegetation patterns in Sudan. Ecography, 34(6), 990-1001. https://doi.org/10.1111/j.1600-0587.2010.06694.x

Denslow, J. S., Space, J. C., \& Thomas, P. A. (2009). Invasive exotic plants in the tropical Pacific islands: patterns of diversity. Biotropica, 4l(2), 162-170. https://doi.org/10.1111/j.1744-7429.2008.00469.x 
Donlan, C. J., \& Wilcox, C. (2008). Diversity, invasive species and extinctions in insular ecosystems. Journal of Applied Ecology, 45(4), 1114-1123. https://doi.org/10.1111/j.1365-2664.2008.01482.x

Duncan, C. A., Jachetta, J. J., Brown, M. L., Carrithers, V. F., Clark, J. K., DiTomaso, J. M., ... Rice, P. M. (2004). Assessing the economic, environmental, and societal losses from invasive plants on rangeland and wildlands. Weed Technology, 18(sp1), 1411-1416. https://doi.org/10.1614/0890-037X(2004)018[1411:ATEEAS]2.0.CO;2

Dunn, R. R. (2010). Global mapping of ecosystem disservices: the unspoken reality that nature sometimes kills us. Biotropica, 42(5), 555-557. https://doi.org/10.1111/j.1744-7429.2010.00698.x

Gardner, T. A., Barlow, J., Sodhi, N. S., \& Peres, C. A. (2010). A multi-region assessment of tropical forest biodiversity in a human-modified world. Biological Conservation, 143(10), 2293-2300. https://doi.org/10.1016/j.biocon.2010.05.017

Ghahramanzadeh, R., Esselink, G., Kodde, L. P., Duistermaat, H., Valkenburg, J. L. C. H., Marashi, S. H., ... Wiel, C. C. M. (2013). Efficient distinction of invasive aquatic plant species from non - invasive related species using DNA barcoding. Molecular ecology resources, 13(1), 21-31. https://doi.org/10.1111/1755-0998.12020

Gordon, D. R. (1998). Effects of invasive, non - indigenous plant species on ecosystem processes: lessons from Florida. Ecological Applications, 8(4), 975-989. https://doi.org/10.1890/1051-0761(1998)008[0975:EOINIP]2.0.CO;2

Griffiths, P., Kuemmerle, T., Baumann, M., Radeloff, V. C., Abrudan, I. V., Lieskovsky, J., ... Hostert, P. (2014). Forest disturbances, forest recovery, and changes in forest types across the Carpathian ecoregion from 1985 to 2010 based on Landsat image composites. Remote Sensing of Environment, 151, 72-88. https://doi.org/10.1016/j.rse.2013.04.022

Guariguata, M. R. (1990). Landslide disturbance and forest regeneration in the upper Luquillo Mountains of Puerto Rico. The Journal of Ecology, 814-832. https://doi.org/10.2307/2260901

Gunderson, L. H. (2000). Ecological resilience-in theory and application. Annual review of ecology and systematics, 31(1), 425-439. https://doi.org/10.1146/annurev.ecolsys.31.1.425

Gurevitch, J., \& Padilla, D. K. (2004). Are invasive species a major cause of extinctions?. Trends in ecology \& evolution, 19(9), 470-474. https://doi.org/10.1016/j.tree.2004.07.005

Hemp, A. (2008). Introduced plants on Kilimanjaro: tourism and its impact. Plant ecology, 197(1), 17-29. https://doi.org/10.1007/s11258-007-9356-Z

Holmes, T. P., Aukema, J. E., Von Holle, B., Liebhold, A., \& Sills, E. (2009). Economic impacts of invasive species in forests. Annals of the New York Academy of Sciences, 1162(1), 18-38. https://doi.org/10.1111/j.1749-6632.2009.04446.x

Howard, R. A., \& Powell, D. A. (1963). The introduction of rubber-producing species in the West Indies. Economic Botany, 17(4), 337-349. https://doi.org/10.1007/BF02860143

Howard, R. A. (1988). Flora of the Lesser Antilles. Leeward and Windward Islands. Volume 4. Dicotyledoneae, Massachusetts: Arnold Arboretum, Harvard University 673p.-illus.. En Keys. Geog.

Hulme, P. E. (2009). Trade, transport and trouble: managing invasive species pathways in an era of globalization. Journal of applied ecology, 46(1), 10-18. https://doi.org/10.1111/j.1365-2664.2008.01600.x

Kairo, M., Ali, B., Cheesman, O., Haysom, K., \& Murphy, S. (2003). Invasive species threats in the Caribbean Region. Report to the Nature Conservancy, Arlington.

Kairo, M. T. K., Pollard, G. V., Peterkin, D., \& Lopez, V. (2000). Biological control of the hibiscus mealybug, Maconellicoccus hirsutus Green (Hemiptera: Pseudoccidae) in the Caribbean. Integrated Pest Management Reviews, 5, 241-254. https://doi.org/10.1023/A:1012997619132

Lawley, V., Parrott, L., Lewis, M., Sinclair, R., \& Ostendorf, B. (2013). Self-organization and complex dynamics of regenerating vegetation in an arid ecosystem: 82 years of recovery after grazing. Journal of Arid Environments, 88, 156-164. https://doi.org/10.1016/j.jaridenv.2012.08.014

Levin, S. A. (2005). Self-organization and the emergence of complexity in ecological systems. Bioscience, 55(12), 1075-1079. https://doi.org/10.1641/0006-3568(2005)055[1075:SATEOC]2.0.CO;2

Lugo, A. E. (2013). Novel tropical forests: nature's response to global change. Tropical Conservation 
Science, 6(3), 325-337. https://doi.org/10.1177/194008291300600303

Mack, M. C., \& D'Antonio, C. M. (1998). Impacts of biological invasions on disturbance regimes. Trends in Ecology \& Evolution, 13(5), 195-198. https://doi.org/10.1016/S0169-5347(97)01286-X

Margono, B. A., Potapov, P. V., Turubanova, S., Stolle, F., \& Hansen, M. C. (2014). Primary forest cover loss in Indonesia over 2000-2012. Nature Climate Change, 4(8), 730-735. https://doi.org/10.1038/nclimate2277

Maunder, M., Leiva, A., Santiago-Valentin, E., Stevenson, D. W., Acevedo-Rodríguez, P., Meerow, A. W., ... Francisco-Ortega, J. (2008). Plant conservation in the Caribbean Island biodiversity hotspot. The Botanical Review, 74(1), 197-207. https://doi.org/10.1007/s12229-008-9007-7

McNeely, J. (2001). Invasive species: a costly catastrophe for native biodiversity. Land Use and Water Resources Research, 1(2), 1-10.

Meyerson, L. A., \& Mooney, H. A. (2007). Invasive alien species in an era of globalization. Frontiers in Ecology and the Environment, 5(4), 199-208. https://doi.org/10.1890/1540-9295(2007)5[199:IASIAE]2.0.CO;2

Murcia, C., Aronson, J., Kattan, G. H., Moreno-Mateos, D., Dixon, K., \& Simberloff, D. (2014). A critique of the 'novel ecosystem'concept. Trends in ecology \& evolution, 29(10), 548-553. https://doi.org/10.1016/j.tree.2014.07.006

Mwavu, E. N., \& Witkowski, E. T. (2009). Seedling regeneration, environment and management in a semi deciduous African tropical rain forest. Journal of Vegetation science, 20(5), 791-804. https://doi.org/10.1111/j.1654-1103.2009.01084.x

Negussie, A., Achten, W. M., Aerts, R., Norgrove, L., Sinkala, T., Hermy, M., \& Muys, B. (2013). Invasiveness risk of the tropical biofuel crop Jatropha curcas L. into adjacent land use systems: from the rumors to the experimental facts. Gcb Bioenergy, 5(4), 419-430. https://doi.org/10.1111/gcbb.12011

Norghauer, J. M., Martin, A. R., Mycroft, E. E., James, A., \& Thomas, S. C. (2011). Island invasion by a threatened tree species: evidence for natural enemy release of mahogany (Swietenia macrophylla) on Dominica, Lesser Antilles. Plos One, 6(4), e18790. https://doi.org/10.1371/journal.pone.0018790

Pejchar, L., \& Mooney, H. A. (2009). Invasive species, ecosystem services and human well-being. Trends in ecology \& evolution, 24(9), 497-504. https://doi.org/10.1016/j.tree.2009.03.016

Peterson, A. T. (2001). Predicting Species'Geographic Distributions Based on Ecological Niche Modeling. The Condor, 103(3), 599-605. https://doi.org/10.1650/0010-5422(2001)103[0599:PSGDBO]2.0.CO;2

Peterson, A. T., Papes, M., \& Kluza, D. A. (2003). Predicting the potential invasive distributions of four alien plant species in North America. Weed Science, 51(6), 863-868. https://doi.org/10.1614/P2002-081

Pimentel, D., Lach, L., Zuniga, R., \& Morrison, D. (2000). Environmental and economic costs of nonindigenous species in the United States. BioScience, 50(1), 53-65.

https://doi.org/10.1641/0006-3568(2000)050[0053:EAECON]2.3.CO;2

Reaser, J. K., Meyerson, L. A., Cronk, Q., De Poorter, M. A. J., Eldrege, L. G., Green, E., ... O'Dowd, D. E. N. N. I. S. (2007). Ecological and socioeconomic impacts of invasive alien species in island ecosystems. Environmental Conservation, 34(2), 98-111. https://doi.org/10.1017/S0376892907003815

Reichard, S. H., \& White, P. (2001). Horticulture as a pathway of invasive plant introductions in the United States: most invasive plants have been introduced for horticultural use by nurseries, botanical gardens, and individuals. BioScience, 51(2), 103-113.

https://doi.org/10.1641/0006-3568(2001)051[0103:HAAPOI]2.0.CO;2

Richardson, D. M., \& Pyšek, P. (2012). Naturalization of introduced plants: ecological drivers of biogeographical patterns. New Phytologist, 196(2), 383-396. https://doi.org/10.1111/j.1469-8137.2012.04292.x

Sakai, A. K., Allendorf, F. W., Holt, J. S., Lodge, D. M., Molofsky, J., With, K. A., ... McCauley, D. E. (2001). The population biology of invasive species. Annual review of ecology and systematics, 32(1), 305-332. https://doi.org/10.1146/annurev.ecolsys.32.081501.114037

Schoelynck, J., De Groote, T., Bal, K., Vandenbruwaene, W., Meire, P., \& Temmerman, S. (2012). Self organised patchiness and scale - dependent bio - geomorphic feedbacks in aquatic river vegetation. Ecography, 35(8), 760-768. https://doi.org/10.1111/j.1600-0587.2011.07177.x

Schofield, E. K. (1989). Effects of introduced plants and animals on island vegetation: examples from Galápagos Archipelago. Conservation Biology, 3(3), 227-239. https://doi.org/10.1111/j.1523-1739.1989.tb00081.x 
Sheil, D., Jennings, S., \& Savill, P. (2000). Long-term permanent plot observations of vegetation dynamics in Budongo, a Ugandan rain forest. Journal of Tropical Ecology, 16(6), 865-882. https://doi.org/10.1017/S0266467400001723

Taylor, S., \& Kumar, L. (2013). Potential distribution of an invasive species under climate change scenarios using CLIMEX and soil drainage: A case study of Lantana camara L. in Queensland, Australia. Journal of environmental management, 114, 414-422. https://doi.org/10.1016/j.jenvman.2012.10.039

Ulgiati, S., \& Brown, M. T. (1998). Monitoring patterns of sustainability in natural and man-made ecosystems. Ecological Modelling, 108(1), 23-36. https://doi.org/10.1016/S0304-3800(98)00016-7

Weerman, E. J., Herman, P. M., \& Van de Koppel, J. (2011). Top - down control inhibits spatial self organization of a patterned landscape. Ecology, 92(2), 487-495. https://doi.org/10.1890/10-0270.1

Yan, X., Zhenyu, L., Gregg, W. P., \& Dianmo, L. (2001). Invasive species in China-an overview. Biodiversity \& Conservation, 10(8), 1317-1341. https://doi.org/10.1023/A:1016695609745

Yang, L., Liu, N., Ren, H., \& Wang, J. (2009). Facilitation by two exotic Acacia: Acacia auriculiformis and Acacia mangium as nurse plants in South China. Forest ecology and management, 257(8), 1786-1793. https://doi.org/10.1016/j.foreco.2009.01.033

Zimmerman, N., Flint Hughes, R., Cordell, S., Hart, P., Chang, H. K., Perez, D., ... Ostertag, R. (2008). Patterns of primary succession of native and introduced plants in lowland wet forests in eastern Hawaii. Biotropica, 40(3), 277-284. https://doi.org/10.1111/j.1744-7429.2007.00371.x

Zohary, D. (2004). Unconscious selection and the evolution of domesticated plants. Economic botany, 58(1), 5-10. https://doi.org/10.1663/0013-0001(2004)058[0005:USATEO]2.0.CO;2

\section{Notes}

Note 1 . Average daily global radiation from 2012 to 2016 is equal to 56100.8 joules $/ \mathrm{cm}^{2}$.

Note 2. The minimum area (or basal area) is the smallest unit area of a floristic station considered homogeneous in terms of mesological or environmental factors including pluviometry, evapotranspiration and humidity, etc.

Note 3. XLSTAT software (new version).

Note 4. These trees formerly made up a sylve corresponding to a more advanced stage of evolution.

Note 5. ID $=$ Id $\times$ ST. ID is an intelligible indicator for homogeneous and little anthropised formations.

Note 6. The basal area (ST) of Funtumia elastica is, in order of significance, in fourth position after Simarouba amara, Inga ingoides and Sapium caribaeum (Table 4).

\section{Copyrights}

Copyright for this article is retained by the author(s), with first publication rights granted to the journal.

This is an open-access article distributed under the terms and conditions of the Creative Commons Attribution license (http://creativecommons.org/licenses/by/4.0/). 